\title{
BOOK REVIEW SECTION
}

Angyl, Andras. Foundations for a science of personality, 177

Bateson, George, and Margaret Mead. Balinese Character, 183

Berman, Louis. Behind the universe, 377

Bills, Arthur G. The psychology of efficiency, 186

Bochner, Ruth, and Florence Halpern. The clinical application of the Rorschach test, 186

Bossard, James H. S., and Eleanor S. Boll. Family situations, 18I

Bowley, Agatha H. Guiding the normal child, 555

Brill, A. A. Freud's contribution to psychiatry, 751

Bruce, William F., and Frank S. Freeman. De. velopment and learning, I 82

Bunch, C. C. Clinical audiometry, 750

Cameron, D. Ewen. Objective and experimental psychiatry, 179

Carr-Saunders, A. M., et al. Young offendersan enquiry into juvenile delinquency, 553

Child, Irvin L. Italian or American? 180

Child Study Assoc. of America. When children ask about sex, 187

Cobb, Stanley, Borderlands of psychiatry, ${ }_{17} 8$

Davis, John Eisle. Principles and practice of rehabilitation, 376

Doshay, Lewis J. The boy sex offender and his later career, 185

Dougherty, William B., and Dagobert Runes, eds. Rehabilitation of the war injured, 183

Draper, George, et al. Human constitution in clinical medicine, 549

Dunbar, Flanders. Psychosomatic diagnosis, 551

Fenton, Norman. Mental hygiene in school practice, $37 \mathrm{I}$

Fink, David $H$. Release from nervous tension, 186

Folsom, J. Kirk. The family and democratic society, 179

Ginsberg, Eli, et al. The unemployed, 376

Hall, J. K., ed. One hundred years of American psychiatry, 553

Hayes, Samuel Perkins. Contributions to a psychology of blindness, 185

Henry, Jules and Zunia. Doll play of Pilaga Indian children, 550

Holt, L. Emmett. The care and feeding of children, 187

Hopkirk, Howard W. Institutions serving children, 750

Hunt, J. Mc. V. Personality and behavior disorders, 747

Ingram, Madalene E. Principles of psychiatric nursing, 554
Institute for psychoanalysis. Women in wartime, 187

Kardiner, Abram. The traumatic neurosis of war, 176

Krains, S. H., and E. S. Thetford. Managing your mind, 186

Landis, Carney, et al. Sex in development, 546

Lawton, George, ed. New goals for old age, 376

Levy, David M. Maternal overprotection, 370

MacCurdy, J. T. The structure of morale, 545

Machover, Solomon. Cultural and racial variations in patterns of intellect, 370

Maurer, Rose. Soviet health care in peace and war, 187

Mira, Emilio. Psychiatry in war, 545

Moore, Dom Thomas V. The nature and treatment of mental disorders, 555

National Probation Assoc. Social defenses against crime, 183

Needham, James G. About ourselves, i 8 r

Newcomb, Theodore M. Personality and social change, 548

N. Y. C. Committee on Mental Hygiene. Child guidance leaflets, 187

Pignatelli, Myrtle L. Comparative study of mental functioning patterns of problem and non-problem children, 187

Preston, $H$. The substance of Mental health, $75 \mathrm{I}$

Reckless, Walter C. The etiology of delinquent and criminal behavior, 187

Ribble, Margaret A. The rights of infants, 546

Rivlin, Harry N., and Herbert Schuler, eds. Encyclopedia of modern education, 554

Rogers, Carl R. Counseling in psychotherapy, 547

Ryberg, Percy E. Health, sex, and birth control, 377

Sigerist, Henry E. Civilization and disease, 549

Silva, Pacheco e, Lectures in Military psychiatry, 749

Smith College School of social work. Papers in honor of Everett Kimball, 47 I

Travis, Lee E., and Dorothy W. Baruch. Personal problems of everyday life, 185

Triggs, Frances O. Remedial reading. Improve your reading. 184

Wechsier, David. The measurement of adult intelligence, 553

Wilkinson, Oscar and Richard W. Strabismus; its etiology and treatment, 373

Winn, Ralph B., ed. Encyclopedia of child guidance, 377

Whyte, William F. Street corner society, $37^{2}$

Zilboorg, Gregory. Mind, medicine and man, 175 